\title{
Ear formation and grain yield of winter wheat as affected by time of nitrogen supply
}

\section{A. Darwinkel}

Research Station for Arable Farming and Field Production of Vegetables, P.O. Box 430, 8200 AK Lelystad, Netherlands

Received 10 June 1983; accepted 10 August 1983

Key-words: winter wheat, main shoots, tillers, nitrogen, split dressing, development stages, yield components

\section{Summary}

A winter wheat crop was provided with an additional nitrogen dressing at different stages between tillering and ear emergence, after a base nitrogen dose applied at the onset of tillering. The effect of nitrogen on ear formation was found to depend greatly on the growth stage at the time of nitrogen application. Maximum effects on growth parameters were achieved at the following developmental stages: (1) tiller formation and spikelet initiation, when additional nitrogen was supplied at the beginning of tillering, (2) ear number, when nitrogen was supplied at the onset of stem elongation, (3) the numbers of fertile spikelets, grains per fertile spikelet and grains per ear when nitrogen was applied during stem elongation until flag leaf emergence and (4) single grain weight when nitrogen was applied at ear emergence. Variations in 1000-grain weights were small, therefore grain yield per ear as well as per unit area was largely determined by grain number.

Main shoots clearly outyielded ear-bearing tillers, because of a substantially higher grain number. In the ear-bearing tillers too, grain yield largely depended upon the grain number, being highest in the old, early-appeared tillers. The grain formation of ear-bearing tillers was more strongly affected by the time of additional nitrogen supply than that of main shoots. So the effect of nitrogen on grain number per ear resulted from its effect on the formation of ear-bearing tillers. Top-dressings of nitrogen applied during stem elongation increased the grain number of earbearing tillers considerably, because both the number of fertile spikelets and the grain number per fertile spikelet were higher. Moreover, in the young late-appeared tillers the optimum time at which to apply additional nitrogen for grain set shifted to later stages of development.

It seems that the poorer grain set of ear-bearing tillers after early nitrogen supply was caused by stronger mutual competition for solar radiation. If top-dressings of nitrogen during stem elongation were postponed until flag leaf emergence, light interception by ear-bearing tillers was favoured by the lower ear density and smaller 
leaf area. Applying nitrogen at ear emergence resulted in poor grain set, presumably because insufficient nitrogen was available during spikelet development.

\section{Introduction}

Nitrogen is the most influential factor for the growth and development of every plant and as such is very important in plant nutrition. In cereals, nitrogen largely affects grain yield and grain quality. High grain yields require a high supply of nitrogen; $250-260 \mathrm{~kg}$ of nitrogen per hectare should be taken up by the crop for producing maximum grain yields (Darwinkel et al., 1983; Spiertz \& Ellen, 1979). However, high rates of nitrogen must be carefully applied to prevent a higher incidence of lodging, diseases and pests (Darwinkel, 1980). In cereal crop management, large amounts of nitrogen will only be profitable if supplementary treatments such as the use of growth regulators, fungicides and pesticides are modified (Dilz \& Schepers, 1974; Dilz et al., 1982; Sturm \& Effland, 1982).

The mode of nitrogen dressing must closely follow the nitrogen demand of the crop during growth and development; the nitrogen supply is split and its application is timed to produce high and stable yields. On marine clay soils in the Netherlands, it is recommended to apply the nitrogen dressing in three doses. Normally, an early dose at growth stage (GS) 20 (Zadoks et al., 1974) is applied to stimulate tillering, and a late one at GS 47 to improve grain-filling and grain protein. In between, additional nitrogen is required for stem and leaf growth and ear development. In the Netherlands, a second nitrogen dose is usually applied at GS 32. However, rapid crop growth starts at the onset of stem elongation (GS 30) and this requires ample nitrogen. This discrepancy in time between demand and supply of nitrogen suggests that nitrogen fertilization is sub-optimal for crop development.

Grain yield is often found to be closely related to the number of grains produced per unit area (Darwinkel, 1978; Dougherty et al., 1978; Ellen \& Spiertz, 1980; Fisher et al., 1977; McLaren, 1981). To study the effect of the timing of nitrogen supply on the grain yield of a winter wheat crop, research was focussed on grain formation in ear-bearing tillers. The results of field experiments carried out in 1979 and 1980 are presented and discussed in this paper.

\section{Materials and methods}

A nitrogen dressing experiment was conducted with winter wheat cultivar Caribo in 1979 and with the cultivars Arminda and Okapi in 1980. Caribo and Okapi descend from the same parentage and differences in yield components are small. Arminda is distinguishable from this two varieties because of its higher ear number, higher grain number per ear and lower 1000-grain weight (57th Dutch Variety List, 1982). Sowing took place on 23 October 1978 and 9 October 1979, respectively and seeds were placed by hand at a spacing of $10 \mathrm{~cm}$ each way. After field emergence, any ungerminated seeds were replaced with seedlings, and so a density of 100 plants per $\mathrm{m}^{2}$ was achieved accurately.

Nitrogen was applied in three doses during the growth period. In both years, the 
Table 1. Schedule of nitrogen applications: timing and splitting of a total nitrogen dressing of $210 \mathrm{~kg} / \mathrm{ha}$.

\begin{tabular}{llllllll}
\hline N treatment & \multicolumn{7}{l}{ Nitrogen applications $(\mathrm{kg} / \mathrm{ha})$ at growth stage (GS)*: } \\
\cline { 2 - 8 } & $20-21$ & 21 & 30 & 32 & 39 & 47 & 52 \\
N1 & 90 & 60 & - & - & - & - & 60 \\
N2 & 90 & - & 60 & - & - & - & 60 \\
N3 & 90 & - & - & 60 & - & - & 60 \\
N4 & 90 & - & - & - & 60 & - & 60 \\
N5 & 90 & - & - & - & - & 60 & 60 \\
\hline
\end{tabular}

* According to the Zadoks/Chang/Konzak scale (Zadoks et al., 1974).

mineral nitrogen in the soil was $50-60 \mathrm{~kg} \mathrm{~N} / \mathrm{ha}$, and according to the nitrogen recommendations the first basal nitrogen dressing was chosen to be $90 \mathrm{~kg} \mathrm{~N} / \mathrm{ha}(=9 \mathrm{~g}$ $\mathrm{N} / \mathrm{m}^{2}$ ), applied at the onset of spring growth (GS 20-21). The second nitrogen dose of $60 \mathrm{~kg} / \mathrm{ha}\left(=6 \mathrm{~g} / \mathrm{m}^{2}\right)$ was applied at 5 different growth stages (GS 21, GS 30, GS 32 , GS 39 and GS 47). A third nitrogen dressing of $60 \mathrm{~kg} / \mathrm{ha}\left(=6 \mathrm{~g} / \mathrm{m}^{2}\right)$ was applied just after ear emergence to all treatments to afford sufficient nitrogen supply for the grain-filling period. The amounts and timing of the 5 nitrogen treatments are presented in Table 1.

Plot size was $1 \mathrm{~m} \times 2 \mathrm{~m}$, including 10 rows of 20 plants each. In the centre of each plot, 20 plants, i.e. 2 rows of $1 \mathrm{~m}$ length, were used to estimate grain yield per unit area. During tillering, main shoots and tillers were marked sequentially with plastic rings of different colours. At harvest, the ear population could easily be classified into main shoots (ms), first emerged tiller ( $t 1)$, second emerged tiller (t2), etc. This classification reflects a time scale of shoot appearance, with main shoots being the oldest shoots and the fifth tiller ( 15 ) being the youngest ear-bearing shoot. Grain yield, 1000-grain weight, grain number and spikelet number were measured in all ear-bearing shoots. In two nitrogen treatments (N1 and N4), the area of the flag, penultimate and third leaves of the distinct ear-bearing shoots were measured at anthesis with a leaf area planimeter.

The experiments, laid down as a randomized block design with 4 replicates, were carried out on a fertile well-textured marine clay loam soil with a high water-holding capacity in the new Flevopolders. Neither waterlogging nor drought should have any effect on crop growth on this well-drained polder soil. Shortage of rainfall may cause a restricted uptake of nitrogen if the latter is applied during a dry spell. For this reason, water was supplied after each dose during the dry spell in the spring of 1980. Any interfering influences that might have caused damage to the plots were obviated by means described earlier (Darwinkel, 1978).

\section{Results}

The experiments were conducted during 2 years with 3 different cultivars. Therefore, differences in crop growth and grain yield might have been caused by genotype as well as by seasonal traits. Grain yields and some yield characteristics are 
Table 2. Average grain yields and yield characteristics of the 3 cultivars (mean of $5 \mathrm{~N}$ treatments).

\begin{tabular}{llllllllr}
\hline Cultivar & Year & $\begin{array}{l}\text { Grain } \\
\text { yield } \\
\left(\mathrm{g} \mathrm{DM} / \mathrm{m}^{2}\right)\end{array}$ & $\begin{array}{l}\text { Shoot } \\
\text { number } \\
\text { per } \mathrm{m}^{2} \\
\text { at GS } 31\end{array}$ & $\begin{array}{l}\text { Ear } \\
\text { number } \\
\text { per m }{ }^{2}\end{array}$ & $\begin{array}{l}\text { Grain } \\
\text { number } \\
\text { per ear }\end{array}$ & $\begin{array}{l}\text { 1000-grain } \\
\text { weight } \\
(\mathrm{g} \mathrm{DM})\end{array}$ & $\begin{array}{l}\text { Harvest } \\
\text { index }\end{array}$ & $\begin{array}{l}\text { Straw } \\
\text { length } \\
\text { (cm) }\end{array}$ \\
Caribo & 1979 & 880 & 1148 & 485 & 39.2 & 46.4 & 48.2 & 94 \\
Okapi & 1980 & 928 & 1301 & 446 & 42.3 & 49.3 & 44.6 & 109 \\
Arminda & 1980 & 790 & 1529 & 411 & 52.9 & 36.4 & 45.8 & 89 \\
\hline
\end{tabular}

presented in Table 2 for the three cultivars used in the experiments. High grain yields were obtained with all 3 cultivars; mean grain yield exceeded $850 \mathrm{~g}$ dry matter per $\mathrm{m}^{2}$, corresponding to 10 tonnes of grains per hectare at $15 \%$ moisture content. Varietal differences in grain yield between Okapi and Arminda were reflected in grain number, 1000-grain weight and straw length. In this experiment, Arminda did not have the anticipated higher ear number, and this may have restricted its grain yield.

All cultivars responded similarly to a top-dressing of nitrogen, although Caribo seemed to be affected more than Okapi and Arminda (Fig. 1). However, as the aim of this research was to investigate the timing of an additional nitrogen supply, to enable the nitrogen effects to be seen more clearly, data about grain yield formation
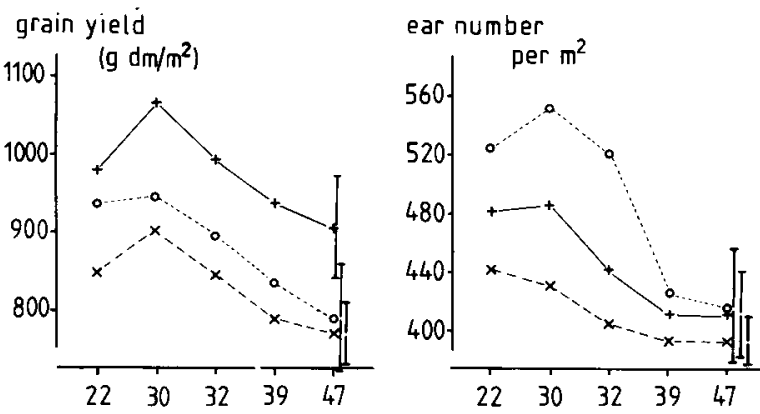

grain number per ear

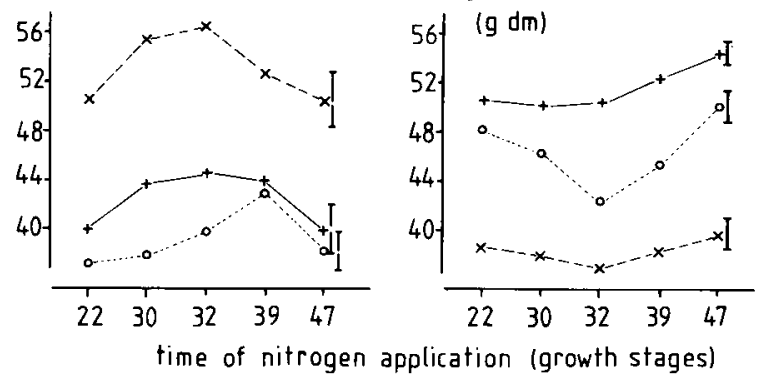

214
Fig. 1. Yield and yield components of 3 wheat cultivars: for Caribo $(o)$ in 1979 and for Arminda $(x)$ and Okapi $(+)$ in 1980 . Confidence intervals have been placed at a confidence coefficient of 0.95 .

Neth. J. agric. Sci. 31 (1983) 
Table 3. Yield determining characteristics of winter wheat at 5 nitrogen regimes. Mean of 3 cultivars grown at 100 plants per $\mathrm{m}^{2}$.

\begin{tabular}{|c|c|c|c|c|c|}
\hline $\mathrm{N}$ treatment & N1 & $\mathrm{N} 2$ & N3 & N3 & N5 \\
\hline Number of main shoots + tillers per $\mathrm{m}^{2}$ & 1413 & 1293 & 1299 & 1290 & 1330 \\
\hline Number of ears per $m^{2}$ & 481 & 487 & 452 & 407 & 407 \\
\hline Shoot fertility $(\%)$ & 34 & 38 & 35 & 32 & 31 \\
\hline Spikelets initiated per ear & 22.7 & 22.2 & 22.1 & 22.3 & 22.4 \\
\hline Barren spikelets per ear & 4.7 & 3.8 & 3.3 & 3.5 & 4.4 \\
\hline Fertile spikelets per ear & 18.0 & 18.4 & 18.8 & 18.8 & 18.0 \\
\hline Spikelet fertility (\%) & 79 & 83 & 85 & 84 & 80 \\
\hline Grains per fertile spikelet & 2.34 & 2.46 & 2.48 & 2.47 & 2.37 \\
\hline Grain number per ear & 42.2 & 45.5 & 46.7 & 46.3 & 42.6 \\
\hline 1000-grain weight (g DM) & 45.6 & 44.6 & 43.8 & 45.4 & 47.5 \\
\hline Grain yield per ear (g DM) & 1.92 & 2.01 & 2.03 & 2.09 & 2.01 \\
\hline Grain yield per $\mathrm{m}^{2}$ (g DM) & 922 & 972 & 917 & 853 & 822 \\
\hline Number of grains per $\mathrm{m}^{2}$ & 20300 & 21700 & 21100 & 18800 & 17300 \\
\hline Harvest index & 46.6 & 47.9 & 47.7 & 48.6 & 47.7 \\
\hline Straw length $(\mathrm{cm})$ & 99 & 98 & 96 & 96 & 95 \\
\hline
\end{tabular}

were averaged over the three varieties. In Table 3 the effect of nitrogen application on crop growth, crop development and grain yield is presented. An early second nitrogen dressing at GS 21 stimulated shoot growth, resulting in a higher number of more vigorous shoots. Highest ear number was achieved when nitrogen was applied at GS 30 ; later nitrogen application clearly reduced ear number. From 100 plants per $\mathrm{m}^{2}$, as used in these experiments, almost all the main shoots and the two oldest tillers formed ears; only a part of the younger tillers was able to produce ears. The time of nitrogen application affected the survival of these younger tillers, resulting in different ear numbers per unit area. The total number of spikelets initiated per ear was hardly affected, but the fertility of the spikelets increased if the nitrogen application was postponed until GS 39. A similar effect was found in the number of grains per fertile spikelet, and as a consequence the number of grains per ear was highest after a second nitrogen dose applied at GS 30,32 or 39 . However, the opposite trend was seen in the 1000-grain weight: up to GS 32 it clearly decreased, but thereafter it increased. Grain yield per ear increased if nitrogen application was postponed until GS 39, but the maximum yield per $\mathrm{m}^{2}$ was attained when nitrogen was applied at GS 30 and decreased with a later application of nitrogen. The effect on harvest index, indicating the ratio of grain yield: total aerial yield, was small and irregular. Straw length was shorter if nitrogen was applied later.

The grain yields of the various ear-bearing shoots are presented in Fig. 2. Main shoots clearly outyielded the tillers in all nitrogen treatments. But among the earbearing tillers a regular pattern was also found: grain yield was lower the later the tiller appeared. In Fig. 2 a different effect of nitrogen supply on the grain yield of the tillers can be observed. The maximum grain yield of the youngest tillers $(t 4,5)$ was obtained when the second nitrogen dose was applied at GS 39 , whereas the older tillers showed maximum grain yields when the nitrogen had been applied earlier. 


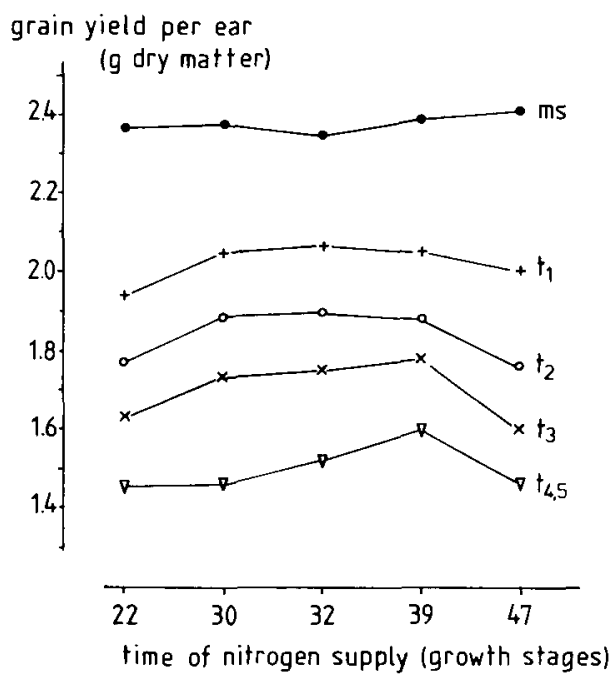

Fig. 2. Grain yield per ear (g DM) of main shoots (ms) and tillers $(t 1 \ldots t 4,5)$ as affected by time of a second nitrogen application (mean of 3 cultivars).

Grain yield per ear is determined by grain number and 1000-grain weight. Data on these yield components are presented in Fig. 3. The results for number of grains per ear mentioned in Table 3 are higher than data from field crops, probably because the plant density in this experiment was approximately half that found in field crops. Grain yield differed considerably among the ear-bearing shoots. The number of grains per ear was higher the earlier the shoot appeared; the main shoot exceeded the youngest tillers $(t 4,5)$ by circa 18 grains per ear. In all shoots, the grain number per ear was influenced by nitrogen supply, but this effect was most pronounced in the tillers. Moreover, the ear-bearing shoots responded differently to the time of nitrogen supply in achieving maximum grain number. For main shoots (ms), maximum grain number was achieved when the second nitrogen dressing was applied at GS 30; for $\mathrm{t} 1$ and $\mathrm{t} 2$ the maximum was achieved after nitrogen application at GS 32, and for $\mathrm{t} 3$ and $\mathrm{t} 4,5$ it was achieved after nitrogen application at GS 39.

In contrast to the number of grains per ear, only small differences in 1000-grain weight were measured between the ear-bearing shoots (Fig. 3). 1000-grain weight was highest in the main shoots and lowest in the youngest tillers $(t 4,5)$, but the differences were less than $4 \mathrm{~g}$. The nitrogen response was similar for all shoots: postponing the second nitrogen dressing until GS 32 decreased 1000-grain weight, but with a further delay the 1000-grain weight rose to the highest value at GS 47 .

The effect of shoot age and the timing of the nitrogen dressing on the numbers of spikelets initiated was small (Fig. 4a). Spikelet number decreased somewhat in younger tillers. Nitrogen enhanced the number of spikelets slightly when applied during the onset of tillering at GS 21. Most of the spikelets initiated formed fertile (= grain-producing) spikelets (Fig. 4b), but at the top and the base of the apex, spikelet formation ceased prematurely, leading to barren spikelets (Fig. 4c). The number of acropetally located barren spikelets was fairly constant, being zero or 
grain number per ear

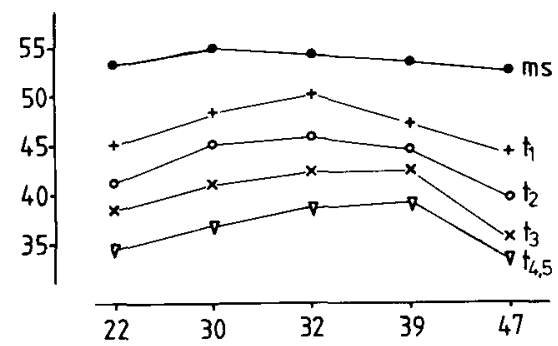

1000 - grain weight

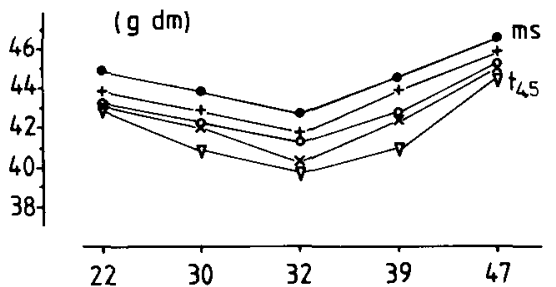

time of nitrogen supply (growth stages)

a. spikelet number per ear

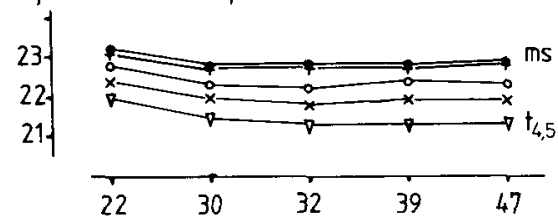

b. number of fertile spikelets per ear

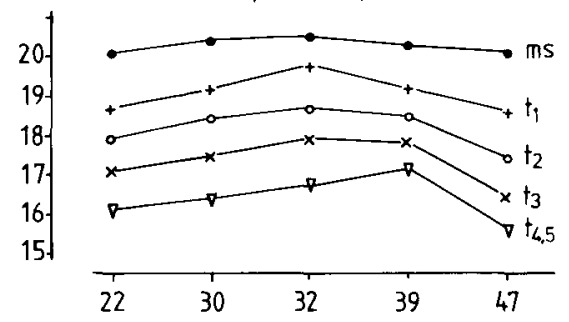

c. number of barren spikelets per eas

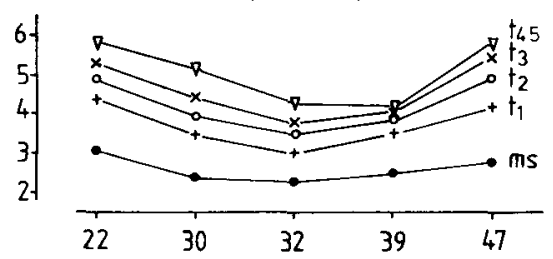

time of nitrogen supply (growth stages)
Fig. 3. Grain number per ear and 1000-grain weight of main shoots (ms) and tillers $(\mathrm{t} 1 \ldots \mathrm{t} 4,5)$ as affected by time of nitrogen supply.
Fig. 4. Number of spikelets per ear (a), fertile spikelets per ear (b) and barren spikelets per ear (c) of main shoots (ms) and tillers (t1 ...t4, 5) as affected by time of nitrogen supply.

Neth. J. agric. Sci. 31 (1983) 


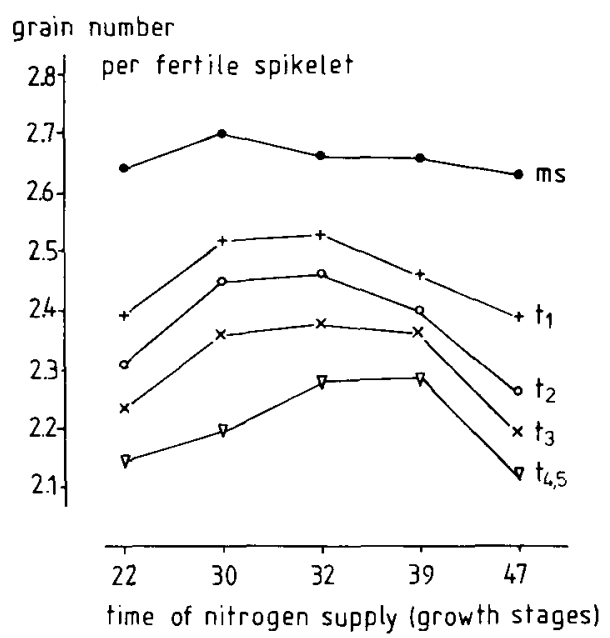

Fig. 5. Grain number per fertile spikelet of main shoots $(\mathrm{ms})$ and tillers $(\mathrm{t} 1 \ldots \mathrm{t} 4,5)$ as affected by time of nitrogen supply.

one per ear. The basipetally located barren spikelets were very variable and were largely influenced by shoot age and timing of nitrogen supply. Main shoots clearly had more fertile spikelets than the tillers. The fertility of the spikelets initiated depended on the timing of nitrogen application. This effect was small in main shoots, but considerable in tillers. Moreover, the younger the tillers, the greater the effect of nitrogen on spikelet development.

The number of grains per fertile spikelet is shown in Fig. 5. There were large differences between the different ear-bearing shoots; main shoots clearly exceeded the tillers, and among the latter considerable differences also occurred. Time of nitrogen application affected the tillers more than the main shoots. Figs. 2 and 3 show that the optimal time of nitrogen application differed for the distinct ear-bearing shoots; the young tillers had the highest grain number per fertile spikelet if the second nitrogen dressing was postponed until GS 39. The interaction between the time of nitrogen application and the shoot age on grain yield formation was most clearly shown in Caribo.

In the 1980 experiment, the growth and nitrogen contents of the developing shoots were monitored for the two cultivars (Arminda and Okapi) in two nitrogen treatments (N1 and N4). Mean data on both cultivars at 4 growth stages are presented in Table 4. At all stages, the dry weights of individual shoots were closely connected to shoot age. The differences in dry weight between the shoots as present at GS 30, continued to increase during growth until harvest (GS 93). The effect of the time of the nitrogen application was small, although at GS 65 and GS 93 the dry weights of the shoots of the N4 treatment tended to be somewhat higher than the $\mathrm{N} 1$ treatment. However, the grain yields per ear of the N4 treatment clearly exceeded those of the $\mathrm{N} 1$ treatment because the grain:straw ratio was higher (see also Table 3).

The nitrogen concentration in all shoots decreased from GS 30 to GS 93 onwards. At GS 30, nitrogen concentration was generally lowest in the main shoots, but was 
Table 4. Dry weights and nitrogen concentrations of main shoots and ear-bearing tillers at 4 growth stages (30, 32, 65 and 93) and 2 nitrogen treatments (N1, N4). Mean of 2 cultivars (Arminda, Okapi), grown in 1980 .

\begin{tabular}{|c|c|c|c|c|c|c|c|c|}
\hline \multirow[b]{2}{*}{$\begin{array}{l}\text { Growth } \\
\text { stage } \rightarrow\end{array}$} & \multicolumn{4}{|c|}{$\mathrm{N} 1: 90 \mathrm{~N}(\mathrm{GS} 20)+60 \mathrm{~N}(\mathrm{GS} 21)+60 \mathrm{~N}(\mathrm{GS} 52)$} & \multicolumn{4}{|c|}{$N 4: 90 N(G S 20)+60 N(G S 39)+60 N(G S 52)$} \\
\hline & 30 & 32 & 65 & 93 & 30 & 32 & 65 & 93 \\
\hline \multicolumn{9}{|c|}{ Dry weights ( $g /$ shoot) } \\
\hline Main shoot & 0.40 & 1.63 & 3.67 & 5.26 & 0.42 & 1.56 & 3.77 & $5.31^{\circ}$ \\
\hline Tiller 1 & 0.31 & 1.31 & 3.17 & 4.59 & 0.32 & 1.32 & 3.30 & 4.61 \\
\hline Tiller 2 & 0.28 & 1.18 & 2.95 & 4.25 & 0.29 & 1.12 & 3.04 & 4.26 \\
\hline Tiller 3 & 0.21 & 0.94 & 2.54 & 3.85 & 0.22 & 0.90 & 2.67 & 3.90 \\
\hline Tiller 4 & 0.15 & 0.70 & 2.23 & 3.25 & 0.15 & 0.78 & 2.24 & 3.38 \\
\hline Tiller 5 & 0.12 & 0.69 & 2.20 & 3.32 & 0.12 & - & 2.05 & 3.43 \\
\hline \multicolumn{9}{|c|}{ Nitrogen contents (\%) } \\
\hline Main shoot & 2.20 & 1.97 & 1.15 & 1.02 & 1.79 & 1.48 & 1.30 & 1.12 \\
\hline Tiller 1 & 2.18 & 2.11 & 1.17 & 1.02 & 1.81 & 1.43 & 1.33 & 1.13 \\
\hline Tiller 2 & 2.18 & 2.11 & 1.15 & 1.03 & 1.86 & 1.48 & 1.32 & 1.12 \\
\hline Tiller 3 & 2.30 & 2.15 & 1.16 & 1.03 & 1.88 & 1.55 & 1.34 & 1.17 \\
\hline Tiller 4 & 2.40 & 2.16 & 1.20 & 1.03 & 1.95 & 1.58 & 1.33 & 1.12 \\
\hline Tiller 5 & 2.40 & 2.33 & 1.20 & 1.03 & 2.00 & - & 1.44 & 1.16 \\
\hline
\end{tabular}

higher in the younger tillers. After GS 32, these differences in nitrogen concentration gradually diminished during growth, and at harvest no differences could be ascertained. At GS 32 the N1 treatment had higher nitrogen contents than the N4 treatment, but at GS 65 and GS 93 the opposite was found, because nitrogen was applied at GS 39 in the N4 treatment.

The 2 cultivars used in the 1980 experiment differed widely in leaf area index. The leaf area, leaf dry weight and specific leaf area (SLA) for the upper 3 leaves were $24.8 \mathrm{~cm}^{2}, 133 \mathrm{mg}$ and $186 \mathrm{~cm}^{2} / \mathrm{g}$, respectively, for Arminda main shoots and for Okapi main shoots they were $30.3 \mathrm{~cm}^{2}, 142 \mathrm{mg}$ and $212 \mathrm{~cm}^{2} / \mathrm{g}$, respectively. However, the effects of shoot age and of nitrogen application were similar for both varieties, and therefore mean data are presented (Table 5). At flowering, the areas of the 3 upper, full-grown leaves of main shoots and tillers in the N1 and N4 treatments were assessed. As expected the flag leaves of these winter wheats were significantly smaller than the penultimate and the 3rd leaves. Moreover, the areas of these leaves decreased in younger shoots. Thus, the total area of the upper 3 leaves was largest in main shoots and smallest in the youngest shoots. The area of every leaf was greatly affected by the time of nitrogen application. The leaf areas per shoot of the N4 treatment were approximately $20 \%$ smaller than those of the N1 treatment.

The small size of flag leaves was associatied with a low leaf dry weight and a small SLA. The SLA was highest in the third leaf and this leaf was similar in size to the penultimate leaf. In younger shoots, dry weights of all leaves were smaller, but SLA was considerably higher. In the N4 treatment, both the dry weights and the 


\section{A. DARWINKEL}

Table 5. Leaf area, dry weight and specific leaf area (SLA) of flag leaves, penultimate and 3rd leaves from main shoot, tiller 2 and tiller 4 at two nitrogen treatments (N1, N4). Mean of 2 cultivars (Arminda, Okapi) at flowering; 1980 experiment.

\begin{tabular}{|c|c|c|c|c|c|c|}
\hline & \multicolumn{3}{|c|}{$\mathrm{N} 1: 90 \mathrm{~N}(\mathrm{GS} 20)+60 \mathrm{~N}(\mathrm{GS} 21)+60 \mathrm{~N}(\mathrm{GS} 52)$} & \multicolumn{3}{|c|}{ N4: $90 \mathrm{~N}(\mathrm{GS} 20)+60 \mathrm{~N}(\mathrm{GS} 39)+60 \mathrm{~N}(\mathrm{GS} 52)$} \\
\hline & $\begin{array}{l}\text { leaf area } \\
\left(\mathrm{cm}^{2}\right)\end{array}$ & $\begin{array}{l}\text { dry weight } \\
\text { (g) }\end{array}$ & $\begin{array}{l}\text { SLA } \\
\left(\mathrm{cm}^{2 / g}\right)\end{array}$ & $\begin{array}{l}\text { leaf area } \\
\left(\mathrm{cm}^{2}\right)\end{array}$ & $\begin{array}{l}\text { dry weight } \\
\text { (g) }\end{array}$ & $\begin{array}{l}\text { SLA } \\
\left(\mathrm{cm}^{2} / \mathrm{g}\right)\end{array}$ \\
\hline \multicolumn{7}{|c|}{ a. Main shoot } \\
\hline $\begin{array}{l}\text { flag leaf } \\
\text { penultimate }\end{array}$ & 21.8 & 0.123 & 178 & 17.4 & 0.106 & 164 \\
\hline leaf & 30.5 & 0.153 & 199 & 25.0 & 0.129 & 194 \\
\hline $\begin{array}{l}\text { third leaf } \\
\text { Totalling }\end{array}$ & 30.4 & 0.136 & 224 & 24.6 & 0.122 & 201 \\
\hline 3 leaves & 82.7 & 0.412 & 201 & 67.0 & 0.357 & 188 \\
\hline \multicolumn{7}{|l|}{ b. Tiller 2} \\
\hline $\begin{array}{l}\text { flag leaf } \\
\text { penultimate }\end{array}$ & 19.3 & 0.096 & 200 & 15.3 & 0.088 & 173 \\
\hline leaf & 26.2 & 0.112 & 234 & 22.3 & 0.112 & 198 \\
\hline $\begin{array}{l}\text { third leaf } \\
\text { Totalling }\end{array}$ & 27.6 & 0.106 & 260 & 22.6 & 0.104 & 217 \\
\hline 3 leaves & 73.1 & 0.314 & 233 & 60.2 & 0.304 & 198 \\
\hline \multicolumn{7}{|l|}{ c. Tiller 4} \\
\hline $\begin{array}{l}\text { flag leaf } \\
\text { penultimate }\end{array}$ & 17.4 & 0.083 & 209 & 12.3 & 0.059 & 208 \\
\hline leaf & 21.9 & 0.090 & 243 & 16.7 & 0.070 & 237 \\
\hline $\begin{array}{l}\text { third leaf } \\
\text { Totalling }\end{array}$ & 22.9 & 0.084 & 272 & 19.3 & 0.074 & 259 \\
\hline 3 leaves & 62.2 & 0.257 & 242 & 48.2 & 0.203 & 237 \\
\hline
\end{tabular}

SLA were lower than in the N1 treatment. The time at which the nitrogen was applied did not interact with shoot age nor with leaf number in terms of leaf area, leaf dry weight and specific leaf area.

\section{Discussion}

The supply of nitrogen to crop stands can differ in rate, in splitting and in application time; therefore the effect of nitrogen supply on grain yield can be variable. Grain yield has often been found to increase with higher nitrogen rates until it reaches a maximum. This increase has usually been mainly caused by the positive effect of nitrogen on ear number and on grain number per ear and as such on the grain number per unit area, whereas 1000-grain weight has varied only slightly (Gliemeroth \& Kübler, 1977; Pearman et al., 1978; Scott et al., 1977; Spiertz \& van Keulen, 1980; Whingwiri \& Stern, 1982). In the experiments reported in this paper grain yield also depended mainly on grain number, which differed according to when the split nitrogen dressing was applied. After having applied an initial nitrogen supply at the start of tillering (GS 20-21), additional nitrogen applied at differ- 
Table 6. Leaf area $\left(\mathrm{cm}^{2}\right)$ of fully grown flag leaves, penultimate and third leaves of main shoots and earbearing tillers at $2 \mathrm{~N}$-treatments. Mean of 2 cultivars (Arminda, Okapi); 1980 experiment.

\begin{tabular}{|c|c|c|c|c|c|c|c|c|}
\hline & \multicolumn{4}{|c|}{$\mathrm{N} 1: 90 \mathrm{~N}(\mathrm{GS} 20)+60 \mathrm{~N}(\mathrm{GS} 21)+60 \mathrm{~N}(\mathrm{GS} 52)$} & \multicolumn{4}{|c|}{$\mathrm{N} 4: 90 \mathrm{~N}(\mathrm{GS} 20)+60 \mathrm{~N}(\mathrm{GS} 39)+60 \mathrm{~N}(\mathrm{GS} 52)$} \\
\hline & $\begin{array}{l}\text { flag } \\
\text { leaf }\end{array}$ & $\begin{array}{l}\text { penult. } \\
\text { leaf }\end{array}$ & $\begin{array}{l}\text { 3rd } \\
\text { leaf }\end{array}$ & $\begin{array}{l}\text { total of } \\
3 \text { leaves }\end{array}$ & $\begin{array}{l}\text { flag } \\
\text { leaf }\end{array}$ & $\begin{array}{l}\text { penult. } \\
\text { leaf }\end{array}$ & $\begin{array}{l}\text { 3rd } \\
\text { leaf }\end{array}$ & $\begin{array}{l}\text { total of } \\
3 \text { leaves }\end{array}$ \\
\hline Main shoot & 21.8 & 30.5 & 30.4 & 82.7 & 17.4 & 25.0 & 24.6 & 67.0 \\
\hline Tiller 1 & n.d.* & n.d. & n.d. & - & 16.5 & 23.0 & 23.2 & 62.7 \\
\hline Tiller 2 & 19.3 & 26.2 & 27.6 & 73.1 & 15.3 & 22.3 & 22.6 & 60.2 \\
\hline Tiller 3 & n.d. & n.d. & n.d. & - & 13.3 & 18.5 & 19.4 & 51.2 \\
\hline Tiller 4 & 17.4 & 21.9 & 22.9 & 62.2 & 12.3 & 16.7 & 19.2 & 48.2 \\
\hline Tiller 5 & n.d. & n.d. & n.d. & - & - & - & - & 44.3 \\
\hline
\end{tabular}

* n.d. = not determined.

ent stages of crop development resulted in different patterns of grain production.

A second nitrogen application mainly favoured shoot number if applied at early tillering (GS 21); it favoured ear number if applied at GS 30, grain number per ear if applied at GS 32, and grain weight if applied at GS 47. Results from similar experiments done by Gliemeroth \& Kübler (1977) were less clear, but those of Knopf (1977) and Niehoff (1978) were more pronounced because of a rather extreme trial lay-out. In our experiments, the 3 cultivars used clearly differed in grain yield formation (Table 2), but their response to nitrogen was similar (Fig, 1).

Nitrogen applied at the onset of stem elongation (GS 30) promoted ear formation because the fertility of the initiated shoots increased. Tiller survival mainly depends on the supply of carbohydrates and of nitrogen. Because the plants were grown 10 $\mathrm{cm}$ apart, inter-plant competition during tillering was negligible. An early application of nitrogen at GS 21 promoted tiller formation, which subsequently resulted in an enhanced intra-plant competition for carbohydrates; if application had been postponed until GS 32 or later, nitrogen might have been suboptimal during tiller growth. The growth of many of the tillers stagnated and, as a consequence, these tillers were too small to produce ears (Masle-Meynard, 1981). Main shoots and early-emerged tillers showed favourable growth and many produced ears; only a small proportion of the young, late-formed tillers survived, but these ears have a low yield potential (Darwinkel, 1978).

Postponing the nitrogen supply until GS 39 decreased ear number, but promoted ear development. The number of spikelets initiated was fairly constant; only an early nitrogen application at GS 21 was able to increase this number to some extent, as was also found by Dougherty et al. (1975) and Scott et al. (1977). Whingwiri \& Kemp (1980) found a substantial reduction in spikelet number when nitrogen supply was very low, but this was probably caused by severe nitrogen deficiency from the time of emergence onwards; at higher rates of nitrogen the increase was also rather small.

Dougherty et al. (1975) obtained experimental evidence that grain set in wheat in the field under conditions of adequate nitrogen was dependent upon assimilate supply to the developing ear. Langer \& Liew (1973) found that the number of fertile 
spikelets was only affected if nitrogen was applied just after double ridge stage, whereas the number of grains was influenced by nitrogen applied up to ear emergence. In our experiments, nitrogen applied at growth stages 30, 32 and 39 increased the number of grains per fertile spikelet and, as a consequence, the number of grains per ear. These yield components were clearly lower if nitrogen was applied early (GS 21) or late (GS 47). The rates and durations of floret initiation did not seem to be affected by nitrogen applications (Whingwiri \& Stern, 1982), so nitrogen application must have affected spikelet degeneration. After an early second nitrogen application at GS 21 most of the tillers produced grew vigorously, causing serious intra-plant competition, which restricted assimilate supply for floret growth and grain set. Nitrogen applied during stem elongation (GS 30, 32 and 39) stimulated growth and, because fewer sizeable tillers were present, more assimilates must have been available for spikelet and floret growth, as was postulated by McLaren (1981). This nitrogen application improved grain set, particularly in the basal spikelet positions, which are susceptible tot barrenness; similar results were found by Langer \& Liew (1973).

Grain weight did not fully compensate for the lower grain numbers per ear. So, grain yield per ear was increased by postponing nitrogen application until GS 39, but decreased when nitrogen was applied at GS 47 . This implies that the strategy for nitrogen supply should be adapted to plant density. In dense plant populations many ears originate from main shoots and early-appeared tillers. The production of these shoots seems to be only slightly affected by the time at which additional nitrogen is applied (Fig. 2). In order to reduce lodging it would be worthwhile applying the second nitrogen gift late during the stage of stem elongation (GS 32 up to GS 39), to favour ear development. In contrast, when plant density is low, nitrogen should be applied at the onset of stem elongation (GS 30) to boost ear formation as well as ear development.

In accordance with earlier research data (Darwinkel, 1978), large differences in grain yield were found between ears from main shoots and tillers, but also among the various tillers. These differences were largely caused by the number of grains per ear and to a small degree by 1000-grain weight. The differences in the number of spikelets initiated were rather small. However, the number of fertile spikelets decreased considerably in younger ear-bearing shoots because of lower spikelet fertility. Moreover, in younger shoots, grain set in the fertile spikelets was poorer, and consequently the number of grains per ear gradually declined. The findings of Whingwiri \& Kemp (1980) that grain yield per ear is more dependent on the number of fertile spikelets per ear and on the number of grains per fertile spikelet than on total spikelet number, were found to be valid for all ears produced in a winter wheat crop. This result is the more striking, because the grains showed only a small variation in 1000-grain weight.

The grain yield formation of ears from tillers was much more affected by time of nitrogen supply than that of ears from main shoots. Moreover, the optimal time of nitrogen application shifted to later stages in younger ear-bearing shoots; this was strongly pronounced in grain number per fertile spikelet and per ear. For main shoots, grain number was highest if nitrogen was applied at GS 30 ; grain number for 
the two oldest tillers ( $\mathrm{t} 1, \mathrm{t} 2)$ was highest if nitrogen was applied at GS 32, and for the youngest tillers $(\mathrm{t} 3, \mathrm{t} 4,5)$ it was highest if nitrogen was applied at GS 39 .

In this research, the time of nitrogen application was characterized by the scale of growth stages in cereals designed by Zadoks et al. (1974), which is based on the de. velopmental stage of the main shoot. Tillers emerge and develop later and, as such, are physiologically younger than indicated by this development scale at any time during crop growth; this is most pronounced for the late-appeared, ear-bearing tillers $(\mathrm{t} 4,5)$. It may be assumed that these differences in development will interfere in the response of the various ear-bearing shoots to an additional application of nitrogen. However, the different responses to nitrogen can only partly be attributed to differences in development between the various ear-bearing shoots. Unpublished data from an earlier experiment with cv. Caribo showed that the 5 th ear-bearing tiller ( $t 5)$ reached the second node stage (GS 32) only 6 days after the main shoot; at flag leaf appearance (GS 39) this lag was even reduced to 4 days.

Shoot growth largely depended on when the shoot appeared (Table 4). At the onset of stem elongation (GS 30), dry weight was highest in main shoots and gradually decreased in younger ear-bearing tillers. In contrast, nitrogen concentrations increased in younger tillers. The differences in shoot dry weight continued to increase during the growth period, but the differences in nitrogen concentrations disappeared. In a crop stand, young tillers are unfavourably situated at the plant base and have a shorter growth period than main shoots (Stern \& Kirby, 1979). Therefore, the carbohydrate supply for ear development is restricted, and this may contribute to the lower number of grains in the young tillers.

An early additional nitrogen application during tillering not only increased ear number, but also the leaf area of each shoot, mainly by a high specific leaf area. In the dense crop stand so created, much light must have been intercepted by main shoots and, because of their unfavourable position in the crop, young ear-bearing tillers probably received less light. Consequently, carbohydrate supply in these young tillers would have been restricted, which may have reduced grain set. Postponing the nitrogen application until GS 39 resulted in fewer ears as well as in a smaller leaf area of all ear-bearing shoots. In such a more open crop situation, a high proportion of the light can be intercepted by ear-bearing tillers. This would enhance carbohydrate supply in these tillers, and would favour grain setting. Although nitrogen supply may not affect floret initiation (Whingwiri \& Stern, 1982), the setting of grains seemed to be largely dependent on nitrogen supply. Nitrogen applied at GS 47 was too late to achieve a high grain number per ear, but it clearly favoured grain-filling.

Grain weight was slightly influenced by nitrogen supply. Again, only a small variation was found among the ear-bearing shoots. Therefore, under optimum growing conditions during the grain-filling period, grain yield is largely determined by the number of grains produced. To achieve a high grain number per unit area, the optimum time to apply the second nitrogen dose was at the beginning of stem elongation (GS 30). To prevent lodging, a delay of this second nitrogen dressing until GS 31-32 would be preferable for commercial wheat growing; in order to maintain yield potential, the initial plant density seemed to be higher. 


\section{Acknowledgement}

The constructive and critical discussions during the preparation of the manuscript with Dr K. Dilz, Ir W. Meijer, Ir N. M. de Vos and Dr J. H. J. Spiertz are gratefully acknowledged.

\section{References}

Darwinkel, A., 1978. Patterns of tillering and grain production of winter wheat at a wide range of plant densities. Netherlands Journal of Agricultural Science 26: 383-398.

Darwinkel, A., 1980. Grain production of winter wheat in relation to nitrogen and diseases. Zeitschrift für Acker- und Pflanzenbau 149: 299-317.

Darwinkel, A., K. Dilz \& J. H. Schepers, 1983. De stikstofbehoefte en de stikstofbemesting van wintertarwe op kleigrond. Bedrijfsontwikkeling 14: 337-340.

Dilz, K. \& J. H. Schepers, 1974. Stikstofbemesting van granen. 25. Effect van bestrijding van afrijpingsziekten met benomyl op de stikstofreactie van winter- en zomertarwe met en zonder toepassing van chloormequat. Proeven 1972 en 1973. Stikstof (7): 110-115.

Dilz, K., A. Darwinkel, R. Boon \& L. M. J. Verstraeten, 1982. Intensive wheat production as related to nitrogen fertilization, crop protection and soil nitrogen: Experience in the Benelux. Proceedings Fertiliser Society 211: 93-124.

Dougherty, C. T., W. R. Scott \& R. H. M. Langer, 1975. Effects of sowing rate, irrigation and nitrogen on the components of yield of spring-sown semidwarf and standard New Zealand wheats. New Zealand Journal of Agricultural Research 18: 197-207.

Dougherty, C. T., B. G. Love \& N. S. Mountier, 1978. Response surfaces of semidwarf wheat for seeding rate, and levels and times of application of nitrogen fertiliser. New Zealand Journal of Agricultural Research 21: 655-663.

Ellen, J. \& J. H. J. Spiertz, 1980. Effects of rate and timing of nitrogen dressings on grain yield formation of winter wheat (T. aestivum L.). Fertiliser Research 1: 177-190.

Fisher, R. A., I. Aquilar \& D. R. Laing, 1977. Post-anthesis sink size in a high-yielding dwarf wheat: Yield responses to grain number. Australian Journal of agricultural Research 28: 165-175.

Gliemeroth, G. \& E. Kübler, 1977. Ertragsaufbau von Winterweizen bei underschiedlich aufgeteilten Stickstoffmengen in Abhängigkeit von dem N-Mineralisationsvermögen pseudovergeleyter Parabraunerden. Zeitschrift für Acker- und Pflanzenbau 144: 165-186.

Knopf, H. E., 1977. N-Angebot und N-Aufnahme und ihr zeitlichter Bezug zur Ertragsbildung bei Winterweizen und Wintergerste. Dissertation, Bonn, pp. 1-135.

Langer, R. H. M. \& F. K. Y. Liew, 1973. Effects of varying nitrogen supply at different stages of the reproductive phase on spikelet and grain production and on grain nitrogen in wheat. Australian Journal Agricultural Research 24: 647-656.

Masle-Meynard, J., 1981. Élaboration du nombre d'épis d'un peuplement de blé d'hiver en situation de compétition pour l'azote. I. Mise en évidence d'un stade critique pour la montée d'une talle. Agronomie 1: 623-632.

McLaren, J. S., 1981. Field studies on the growth and development of winter wheat. Journal of Agricultural Science, Cambridge 97: 685-697.

Niehoff, K. H., 1978. Möglichkeiten der Kompensation witterungsbedingter Schwankungen der Ertragsstruktur einiger Weizen- und Gerstensorten durch variierte N-Ernährung. Dissertation, Kiel, pp. 1-185.

Pearman, I., S. M. Thomas \& G. N. Thorne, 1978. Effect of nitrogen fertilizer of growth and yield of semi-dwarf and tall varieties of winter wheat. Journal of Agricultural Science, Cambridge 91: 31-45.

Scott, W. R., C. T. Dougherty \& R. H. M. Langer, 1977. Development and yield components of highyielding wheat crops. New Zealand Journal of Agricultural Research 20: 205-212.

Spiertz, J. H. J. \& J. Ellen, 1979. Effecten van weersfactoren en stikstofvoeding op de korrelopbrengst en het eiwitgehalte van tarwe. Stikstof 7 (92): 245-251. 
Spierts, J. H. J. \& H. van Keulen, 1980. Effects of nitrogen and water supply on growth and grain yield of wheat. Proceedings International Wheat Conference (Madrid): 595-610.

Stern, W. R. \& E. J. M. Kirby, 1979. Primordium initiation at the shoot apex in four contrasting varieties of spring wheat in response to sowing date. Journal of Agricultural Science, Cambridge 93: 203215.

Sturm, H. \& H. Effland, 1982. Nitrogen fertilization and its interaction with other cultural measures: experiences in the Federal Republic of Germany. Proceedings Fertiliser Society 211: 5-32.

Whingwiri, E. E. \& D. R. Kemp, 1980. Spikelet development and grain yield of the wheat ear in response to applied nitrogen. Australian Journal of Agricultural Research 31: 637-647.

Whingwiri, E. E. \& W. R. Stern, 1982. Floret survival in wheat: significance of the time of floret initiation relative to terminal spikelet formation. Journal of Agricultural Science, Cambridge 98: 257-268.

Zadoks, J. C., T. T. Chang \& C. F. Konzak, 1974. A decimal code for growth stages of cereals. Weed Research 14: 415-421. 